\title{
Razvoj aritmetičnih sposobnosti
}

\author{
Tatjana Levstek ${ }^{*}$, Tina Bregant ${ }^{2}$ in Anja Podlesek ${ }^{3}$ \\ ${ }^{1}$ Gimnazija Ledina \\ ${ }^{2}$ Ambulanta za predšolske otroke, Zdravstveni dom Medvode \\ ${ }^{3}$ Oddelek za psihologijo, Filozofska fakulteta, Univerza v Ljubljani
}

Povzetek: Aritmetika je veja matematike, ki se ukvarja s števili. Ime izhaja iz grške besede "arithmos", ki pomeni število. Poznavanje števil je nujno za razumevanje matematike, zato je razvoj aritmetičnih sposobnosti področje dolgoletnega znanstvenega raziskovanja. Novejše raziskave so pokazale, da razvoj aritmetičnih sposobnostih ne temelji zgolj na pridobivanju izkušenj in učenju, temveč so nam nekatere aritmetične sposobnosti, predvsem občutek za količino, vrojene. Že dojenčki so sposobni razlikovati množici z različnimi elementi, številčnost pa dojemajo amodalno. Pri šestih mesecih ločijo množici, katerih število elementov je v razmerju $1: 2$, s starostjo pa se to razmerje hitro izboljšuje. Petletni otroci že ločijo skupini, katerih število elementov je v razmerju $7: 8$. Sposobnost primerjanja dveh količin se začne razvijati šele po 15 . mesecu starosti, preštevanja pa se otroci naučijo spontano, z učenjem jezika. Govor otroku omogoči, da števila dobijo abstrakten, simbolni pomen, s tem pa se odpre pot k simbolni aritmetiki. Otroci v predšolskem obdobju računajo po intuiciji, v šoli pa aritmetika temelji na učenju postopkov za reševanje problemov. Pri šolskem usvajanju matematičnih znanj prevzame glavno nalogo spomin in avtomatizacija procesov, pri čemer intuicijo zapostavimo. Vendar so raziskave pokazale, da je intuicija zelo pomembna in je celo napovedni dejavnik razvoja matematičnih kompetenc preko celotnega šolanja.

Ključne besede: števila, matematika, matematične sposobnosti, razvoj otroka

\section{Development of arithmetical abilities}

\author{
Tanja Levstek ${ }^{1}$, Tina Bregant ${ }^{2}$ and Anja Podlesek ${ }^{3}$ \\ ${ }^{1}$ Ledina Gymnasium, Ljubljana, Slovenia \\ ${ }^{2}$ Department for Pre-school Children, Health Center Medvode, Slovenia \\ ${ }^{3}$ Department of Psychology, Faculty of Arts, University of Ljubljana, Slovenia
}

\begin{abstract}
Arithmetic (from the word 'arithmos' which means 'numbers') is an elementary branch of mathematics. Numeracy is essential for understanding mathematics, so the development of arithmetic abilities has been an area of scientific research for a long time. Recent research has shown that the development of arithmetic abilities is not based only on gaining experience and learning. Some arithmetic abilities, especially the sense of quantity, are innate. Even babies are able to distinguish between groups with different number of elements and they perceive numeracy amodally. Six-month-olds distinguish between two groups with the numeracy ratio of $1: 2$. With age this ratio improves rapidly. Five-year-old children already distinguish between groups with the number ratio $7: 8$. The ability to compare two quantities begins to develop after 15 months of age and children learn how to count spontaneously, together with the acquisition of language. Speech enables children to understand number in its abstract, symbolic sense, thus opening the way to symbolic arithmetic. During the preschool period children use intuition when doing calculations, but in school the arithmetic is based on the knowledge of arithmetical algorithms. So, in order to acquire mathematical knowledge, it is necessary to incorporate memory and automate arithmetical processes, without the use of intuition. However, research has shown that intuition is very important and is even a predictive factor for the development of mathematical abilities throughout the schooling process.
\end{abstract}

Keywords: numbers, mathematics, mathematical ability, child development

\footnotetext{
"Naslov/Address: Tatjana Levstek, Gimnazija Ledina, Resljeva cesta 12, 1001 Ljubljana, e-mail: tanja.levstek@guest.arnes.si

Članek je licenciran pod pogoji Creative Commons Attribution 4.0 International licence. (CC-BY licenca).

The article is licensed under a Creative Commons Attribution 4.0 International License (CC-BY license).
} 
Dežek pada cele dni, še ponoči nam rosi in namaka luže tri: v prvi luži žabica, v drugi luži račkica, v tretji luži sem pa jaz; vsi kričimo na ves glas.

[ljudska izštevanka]

S števili se začnemo srečevati že zelo zgodaj, v ranem otroštvu. Otroci se učijo imen števil ob pesmicah in rimah, poslušanju štetja odraslega, števila spoznavajo tudi telesno, z ritmičnim korakanjem ali ploskanjem. Skozi igro in ob vsakodnevnih dejavnostih razvrščajo in urejajo, prepoznavajo vzorce in štejejo, usvajajo znanja o prostoru in prostorskih odnosih, kasneje tudi merijo. Tako se srečujejo $\mathrm{z}$ matematiko.

V otrokovem razvoju igra zelo pomembno vlogo razvoj osrednjega živčevja. Na razvojne procese vplivajo tako dedni dejavniki kot okolje, v katerem se otrok razvija. Že med nosečnostjo in v otroštvu se izrazijo manjše genetske posebnosti. Pokaže se lahko tudi precej izrazit vpliv okolja. Radi rečemo, da na razvoj vplivata tako biološka narava oziroma naša genska zasnova kot okolje, ki vključuje zunanje vplive in lahko celo preko epigenetskih sprememb vpliva na izraznost genov. V občutljivem obdobju, ki ga uravnavajo posebne molekule, vezane na biološko notranjo uro, izkušnje nepovratno vplivajo na razvoj posebnih predelov živčevja (Bregant, 2012). V prvih letih življenja se možgani izredno hitro razvijajo. Vzpostavijo se temelji za razvoj govora, učenja, logičnega mišljenja in tudi čustvovanja. Zgodnje otroštvo je kritično obdobje za razvoj večine sistemov v osrednjem živčevju, ki omogočajo veščine in znanja, ki jih potrebujemo kasneje v življenju (Michel in Tyler, 2005). Med pomembne veščine in znanja sodijo tudi aritmetične ali računske sposobnosti, tj. razumevanje in uporaba osnovnih računskih operacij (primerjanje, seštevanje, odštevanje, množenje in deljenje) s števili.

Na vprašanja, kdaj začnemo šteti, kakšen je razvoj matematičnih sposobnosti in kateri dejavniki vplivajo na njihov razvoj, težko najdemo enolične odgovore, so pa novejše raziskave pokazale, da so nam nekatere aritmetične sposobnosti vrojene.

Ocenjevanje številčnosti neke skupine, primerjanje dveh števil oz. količin po velikosti ter osnovno seštevanje (dodajanje) in odštevanje (odvzemanje) so biološko določene sposobnosti in so vrojene tako živalim kot ljudem (Chochon, Cohen, Moortele in Dehaene, 1999; Dehaene, 1997, 2009; Feigenson, Dehaene in Spelke., 2004). Lahko bi jih imenovali tudi 'smisel za števila' ali matematična intuicija, saj te operacije potekajo hitro, avtomatično in brez introspekcije, kar pomeni brez samoopazovanja in analize lastnih občutij, ter tako sledijo trem osnovnim kriterijem, ki opišejo intuicijo (Dehaene, 2009). Matematični intuiciji bi lahko rekli tudi numerična kognicija. Sestavljata jo dva temeljna koncepta: prvi je količina in se nanaša na kardinalnost niza objektov oz. dogodkov ter odgovarja na vprašanje »Koliko?«, drugi koncept pa je rangiranje oziroma razvrščanje in se nanaša na vprašanje »Na kateri poziciji?« (Nieder in Dehaene, 2009).

V razvojuotrokprepoznamorazvojna obdobja,vkaterih lahko opazujemo izrazit telesno-gibalni napredek, čustveni in socialni ter spoznavni razvoj. Teorija kognitivnega razvoja otrok Jeana Piageta pravi, da razvoj sledi časovno določenim stopnjam, ki jih lahko opišemo kot zaznavnogibalna, predoperativna, konkretno operativna in formalno operativna faza (Piaget, 1959, v Marjanovič Umek idr., 2001). Otroci do drugega leta starosti svet doživljajo predvsem skozi telesno-gibalne zaznave in sposobnosti. V zgodnjem otroštvu lahko opazujemo refleksne odzive in večinoma naključno vedenje. Do šestega leta starosti večina otrok razvije simbolno mišljenje, ki presega zaznavne izkušnje. Do enajstega leta večina otrok usvoji logično in fleksibilno mišljenje, razvije se prostorska predstava, sposobnost kategorizacije, iskanja vzročnosti in dojemanja konstantnosti količine. Šele po enajstem letu pa se razvije abstraktno mišljenje, konkretne stvari lahko otrok zamenja s simboli, otroci postanejo zmožni učenja algebre in analize ter razumevanja metafor. Po Piagetovem mnenju poznajo otroci do drugega leta starosti zgolj zaznavno-gibalno razumevanje števil, ne posedujejo pa razumevanja aritmetike. Do šestega leta naj ne bi bili posebej dovzetni za aritmetiko, logično-matematične izkušnje pa naj bi začeli pridobivati šele kasneje, s spominskim oziroma rutinskim učenjem in brez uporabe intuicije (Dehaene, 1997; Batistič Zorec, 2006). Vigotski (1962, v Marjanovič Umek idr., 2001) poudarja pomen učenja, ki je strukturirano tako, da nekoliko presega že doseženo razvojno stopnjo. Meni, da je z učenjem potrebno spodbujati razvoj. Usvajanje kompetenc med vrstniki je zanj ključnega pomena. Tudi Bruner (1966, v Marjanovič Umek idr., 2001) poudarja pomen učenja in trdi, da nobene vsebine same po sebi niso pretežke, saj jih otrok dojema na njemu lasten način.

Razvoj aritmetičnih sposobnosti je zelo pomemben za celosten otrokov razvoj, saj ima poznavanje aritmetike pomembno vlogo tudi pri razvoju ostalih sposobnosti, npr. sposobnost manipulacije $\mathrm{z}$ diskretnimi in s kontinuiranimi vrednostmi, sposobnost logičnega in abstraktnega mišljenja, kategorizacije in razumevanja metafor ... $\mathrm{V}$ prispevku bomo zato predstavili nekaj novejših spoznanj, ki pripomorejo $\mathrm{k}$ boljšemu razumevanju razvoja aritmetičnih sposobnosti otrok. Predstavili bomo dva vrojena sistema reprezentacije števil. Govorili bomo o sistemu aproksimacije količine za velika števila in o sistemu določanja natančnega števila elementov za majhne vrednosti. Pregledali bomo kronološki razvoj aritmetičnih sposobnosti, ki vključuje določanje količine, primerjanje, preštevanje in aritmetiko, od rojstva do odrasle dobe. Vrojene aritmetične sposobnosti (t.i. matematična intuicija) so osnova za učenje aritmetike, zato bomo predstavili tudi rezultate raziskav, ki poudarjajo pomen matematične intuicije za razvoj matematičnih kompetenc v izobraževanju. 


\section{Aproksimacija količine in določanje natančne vrednosti}

Dojenčki že kmalu po rojstvu, pri treh mesecih, postanejo pozorni na številčnost niza predmetov. Pri šestih mesecih vizualno ločijo skupini, ki ju sestavlja 8 in 16 elementov, pri enajstih mesecih pa že izražajo poznavanje ordinalnosti (Dehaene, Molko, Cohen in Wilson, 2004). S. E. Antell in Keating (1983) sta odkrila, da celo novorojenčki, stari le nekaj dni, zaznajo spremembo v številčnosti dve in tri. Uporabila sta paradigmo habituacije in dojenčkom predvajala slike z dvema, tremi, štirimi oz. šestimi pikami. Ugotovila sta, da so novorojenčki zaznali razliko v številu pik na predvajanih slikah, a le za vrednosti dve in tri. Bijeljac-Babič idr. (1993) pa so ugotovili, da so novorojenčki sposobni razčleniti slišane besede na manjše enote, zloge. V eksperimentu so dojenčkom, starim le štiri dni, predvajali besede, sestavljene iz dveh ali treh zlogov, in proučevali njihov odziv $\mathrm{z}$ analiziranjem jakosti sesanja. Ugotovili so, da so dojenčki zaznali razliko $\mathrm{v}$ besedah $\mathrm{z}$ dvema oz. s tremi zlogi, ne glede na dolžino besede in njeno fonetično sestavo. Ker so dojenčki pozorni tako na slušne kot vidne dražljaje, torej na število zvokov kot tudi na število objektov v okolju, lahko sklepamo, da je njihovo dojemanje številčnosti amodalno. Še več, P. Starkey, E. Spelke in R. Gelman (1990) so ugotovile, da dojenčki dojamejo število kot abstraktni pojem. V njihovem eksperimentu so dojenčki, stari od šest do osem mesecev, uspeli povezati dva ali tri slišane zvoke s predvajanimi slikami z dvema oziroma tremi objekti. Dojenčki so torej sposobni prepoznati število zvočnih signalov, četudi se njihovo število med predvajanjem spreminja, injih ustrezno povezati z vizualno predstavitvijo objektov. Zato bi lahko rekli, da je reprezentacija števil pri dojenčkih abstraktna in je najverjenteje neodvisna od učenja jezika in usvajanja drugih veščin. Van Loosbroek in Smitsman (1990) sta V svojem eksperimentu dojenčkom predvajala posnetek z majhnim številom objektov, ki so se s konstantno hitrostjo premikali po ekranu. S paradigmo habituacije sta ugotovila, da petmesečni dojenčki zaznajo razlike v številčnosti objektov, če je le-ta majhna. Pomembna ugotovitev je tudi, da niti sprememba identitete objekta niti sprememba lokacije ne zavedeta dojenčka pri določanju številčnosti. Tako že v prvih mesecih življenja dojenčki dojamejo konstantnost števila objektov v spreminjajočem se okolju. Vendar pa dojenčki uporabljajo le elementarni operaciji dodajanja in odvzemanja. Prav tako ne ločijo številčnosti objektov, če so le-ti različnih barv ali različnih oblik. Ključno vlogo pri dojemanju številčnosti pa igra prostorsko-časovna lokacija objektov, torej kam in kdaj se objekte postavi na sceno (Dehaene, 1997).

Feigenson idr. (2004) so ugotovili, da sta pri dojenčkih in nekaterih živalih prisotna dva sistema reprezentacije števil, ki sta avtomatična in neodvisna od učenja oziroma kulturnega razvoja. Sistema ne vključujeta abstraktnejših konceptov, kot so negativna števila, ulomki, koreni ali realna števila. Razumevanje teh konceptov pridobimo šele kasneje, z izobraževanjem. Gre za osnovno človeško razumevanje števil, vrojeno sposobnost določanja količine, ki je prisotno celotno življenjsko obdobje. Prvi sistem je t. i. ocena velikosti oz. številčnosti skupine elementov. Že šestmesečni dojenčki ločijo številčnost skupin, če je številčnost elementov $v$ razmerju $1: 2$, npr. 8 in 16 elementov, a ne ločijo skupin, če je njihova številčnost v razmerju $2: 3$, npr. 8 in 12 elementov. Desetmesečni dojenček pa uspe ločiti skupini 8 in 12 elementov. J. S. Lipton in E. S. Spelke (2004) sta s predvajanjem zvočnih signalov šest in devet mesecev starim dojenčkom ugotovili, da šestmesečni dojenček loči niza štirih in osmih zvokov, a nizov ne razloči, če je v drugem nizu le šest zvočnih dražljajev. To uspe dojenčku pri starosti devet mesecev, tj. razloči niza, katerih številčnost je v razmerju $2: 3$. Vendar mu pri tej starosti še ne uspe razločiti štirih in petih zvočnih elementov. Xu, Spelke in Goddard (2005) so s paradigmo habituacije preverjali natančnost razločevanja množic $\mathrm{z}$ večjim številom elementov. V eksperimentu so uporabili slike s pikami in odkrili, da šestmesečni dojenčki razločijo tudi skupini s 16 in 32 elementi, ne pa skupini s 16 in 24 elementi, in to ne glede na velikost objektov, zapolnjenost slike $\mathrm{z}$ objekti (pikami), jakost barv pik ali osvetlitev. Zanimivo pa je, da v njihovem poskusu dojenčki niso razločevali številčnosti na slikah $\mathrm{z}$ majhnim številom elementov ( $\mathrm{z}$ eno ali dvema pikama). To postavlja pod vprašaj pretekla dognanja o razločevanju številčnosti majhnega števila vizualno predstavljenih objektov. Dejstvo pa je, da je dojenček sposoben razločevanja količine, še preden usvoji govor ter zmore simbolno računati (Feigenson idr., 2004; Lipton in Spelke 2003, 2004). Aproksimacija torej ni omejena le na vidne objekte, temveč velja tudi za slušne dražljaje. To je še dodatni dokaz, da otroško dojemanje števil temelji na abstraktni reprezentaciji številčnosti, ki je temelj aritmetike.

Tudi starejši otroci in odrasli poznajo sistem aproksimacije številčnosti. Že petletni otroci, tako kot odrasli, ločijo skupini po številčnosti, če sta leti v razmerju $7: 8$ (Feigenson idr., 2004). Otroci se hitro naučijo povezovati simbolična števila $\mathrm{z}$ vrojenim sistemom aproksimacije količine (Dehaene, 1997, 2009). Dojenčki, otroci in odrasli tako poznajo podoben sistem kvantifikacije, omejen $\mathrm{z}$ razmerjem, ki pa $\mathrm{v}$ začetku temelji na logaritmični predstavitvi števil na t. i. mentalni številski osi. To pomeni, da si v mislih ustvarimo podobo - mentalno reprezentacijo števil na številski osi, na kateri pa so razlike med večjimi števili $\mathrm{v}$ primerjavi $\mathrm{z}$ razlikami med manjšimi v začetku predstavljene skrčeno, z njihovimi logaritemskimi vrednostmi. To pomeni, da so razdalje med števili ena in dva, dva in štiri, štiri in osem ... konstantne. Šele z izobraževanjem, približno do četrtega razreda, se logaritmična mentalna predstavitev števil spremeni v linearno (Dehaene, 1997, 2009; Feigenson idr., 2004).

Drugi sistem je sistem določanja natančne vrednosti količine oziroma števila objektov. Otroci in odrasli lahko natančno število elementov določijo le, če teh ni veliko. Dojenčki dojamejo oz. zaznajo spremembo v številčnosti 
elementov, če je število objektov največ tri, ne glede na diskretnost oz. zveznost količine (npr. diskretno je število piškotov, zvezna pa količina materiala) in ne glede na to, katere modalnosti so dražljaji, vidni ali slušni (npr. ne glede na to, ali opazujejo skoke lutke ali zvočne signale; Feigenson idr., 2004). Zato le-ti sklepajo, da gre za dva ločena sistema, kjer je prvi namenjen aproksimaciji večjega števila elementov, drugi pa določanju števila elementov v množici z manj objekti. Razlogov za to je več. Prva domneva je, da ocenjevanje številčnosti majhnega števila elementov ni primerno, saj temelji na oceni zasedenosti oz. napolnjenosti prikazanega področja. Za takšno oceno so pomembne razdalje med objekti, ki pa jih ne moremo definirati, če je objektov premalo (manj kot tri). Drugič, sistem aproksimacije deluje za skupine objektov poljubnih velikosti, vendar je učinek odvisen od opazovanja teh objektov na sceni. Če jih je premalo, npr. le dva, lahko dojenčki usmerijo pozornost zgolj na enega in enostavno ne registrirajo kardinalnosti množice. In tretjič, reprezentacija približne številčnosti lahko poteka na različnih naborih elementov, vendar se pri majhnem številu elementov novosti predstavljenega nabora enostavno ne zaznajo (Xu idr., 2005).

Pri odraslih je povezava med določanjem natančnega, majhnega števila elementov in simbolnimi števili še nejasna. Preštevanje je nezmotljivo in avtomatično, če število elementov ni več kot 4, kar imenujemo subitizacija. $Z$ večanjem števila elementov se napake močno povečujejo (Dehaene, 1997). Zato se domneva, da gre za drugačno procesiranje majhnih oziroma velikih števil, ki vključuje pozornost in delovni spomin (Hyde, 2011). Možna je tudi razlaga, da so majhna števila predstavljena s prvim sistemom aproksimacije količine, ker pa je število majhno, napak enostavno ni (Feigenson idr., 2004).

\section{Primerjanje}

Čeprav dojenček prične uporabljati elementarno seštevanje in odštevanje že kmalu po rojstvu, se primerjanje dveh števil, torej ugotavljanje, da je npr. tri več kot ena, in njihovo razvrščanje, začne kasneje. Raziskave (Dehaene, 1997) so pokazale, da se preštevanje in razvrščanje ne začne pred petnajstim mesecem starosti. E. M. Brannon (2002) je ugotovila, da se sposobnost določanja, katero število je večje oziroma manjše, razvije med devetim in enajstim mesecem starosti. Ugotovila je tudi, da se sposobnost nenumeričnega določanja ordinalnosti, npr. primerjanje likov (kvadratov) po velikosti, razvije pred numeričnim določanjem. Odločitev, katero (arabsko) število je večje, pa odrasli hitreje sprejmejo, če imajo opravka z manjšimi števili in s števili, ki so med seboj po vrednosti bolj oddaljena. Na hitrost in pravilnost odločitve tako vplivata velikost primerjanih števil in razlika med njima. S podvojitvijo števila elementov $\mathrm{v}$ referenčni množici se podvoji tudi razlika med številoma elementov v množicah, kateri primerjamo, da dosežemo pri določanju številčnosti enak delež pravilnih odgovorov. To pravilo imenujemo Webrov zakon, ki pravi, da je količnik med razliko dveh števil, ki predstavljata moči danih množic (moč množice je število elementov le-te), in številom elementov v referenčni množici, konstanten.

$$
W=\frac{\Delta m}{M} \sim \text { konstanta }
$$

$\Delta m=$ razlika med močjo prve in druge množice $M=$ moč referenčne množice

Razločevanje množic glede na številčnost velja tako za dojenčke kot za odrasle, a se Webrova konstanta za številčnost s starostjo zmanjšuje, kar pomeni, da postaja razločevanje množic bolj natančno (Dehaene, 1997; Lipton in Spelke, 2004). Prepoznavanje številčnosti neke množice, ki sledi Webrovemu zakonu, je enako tudi pri živalih. Kar pa nas loči od živali, je simbolna predstava števil. Z učenjem razvijemo sposobnost povezovanja različnih senzornih modalitet in tudi števila začnemo uporabljati transmodalno. Tako števila in aritmetika dobijo simbolni, abstraktni pomen. Zanimiva pa je tudi ugotovitev, da vsako simbolno število nezavedno in avtomatično transformiramo $\mathrm{v}$ njegovo kvantitativno vrednost (Dehaene, 1997).

Števila so povezana tudi s prostorsko predstavo in orientacijo. Majhna števila si predstavljamo na levi strani, velika števila pa na desni (Dehaene, 1997; Hyde, 2011). Vendar pa je orientacija od leve proti desni kulturno pogojena in je odvisna predvsem od načina naše pisave (npr. od leve proti desni). Tako imamo t.i. orientirano mentalno številsko os, s pomočjo katere vsakemu številu poiščemo ustrezno količinsko vrednost. Naša intuicija za števila pa je omejena le na naravna števila od 1 naprej, medtem ko si ostala števila, npr. cela, racionalna, realna ali kompleksna števila težje predstavljamo. Gre namreč za abstraktne pojme, katerih usvajanje lahko povzroči otrokom veliko težav (Dehaene, 1997).

\section{Preštevanje}

Šele z govorom se otrokom odpre pot k simbolnemu računanju. R. Gelman in R. Gallistel (1978) sta ugotovili, da imajo otroci vrojeno sposobnost preštevanja elementov, za katero ne potrebujejo učenja. Zelo zgodaj in brez učenja ugotovijo, da je preštevanje abstraktni postopek, ki ga lahko uporabijo za predmete in zvoke. Do tretjega leta starosti štejejo brez težav do 10, tri in pol letni otrok zazna napako $\mathrm{v}$ preštevanju, do četrtega leta pa usvoji osnovni princip preštevanja. Pravilno štetje pomeni, da je vsak predmet štet le enkrat in da si števila sledijo zaporedno. To je vrojena sposobnost, ki se razvija vzporedno s sposobnostjo spontanega učenja jezika. Šele po četrtem letu starosti otroci začenjajo razumeti, čemu je preštevanje namenjeno, tj. da končno število predstavlja število vseh elementov $\mathrm{v}$ skupini. S preštevanjem otroci usvojijo tudi osnovne principe seštevanja in odštevanja, brez eksplicitnega učenja. Prvi načini seštevanja potekajo z uporabo prstov. Brez uporabe prstov je otrokom računanje 
bistveno težje. Običajno seštevajo tako, da začno z večjim izmed dveh členov, kar izboljša hitrost računanja. To pa tudi pomeni, da otroci uporabljajo zakon o zamenjavi ali komutativnost intuitivno in razvijejo svojo metodo seštevanja že v predšolskem obdobju (Dehaene, 1997). Tudi J. S. Lipton in E. S. Spelke (2006) sta ugotovili, da otroci že v predšolskem obdobju razvijejo simbolni sistem za reprezentacijo števil. Besede za tista števila, katere otroci uporabljajo $\mathrm{v}$ preštevanju, se transformirajo v njihovo nesimbolno vrednost, tj. količino, medtem ko se pri večjih številih to ne zgodi. Vendar sta avtorici odkrili, da otroci, stari pet do šest let, vseeno razumejo 'logiko' preštevanja tudi za velika števila. V nalogi odvzemanja oz. dodajanja elementa številu 86 so otroci razumeli, da se osnovno število spremeni, čeprav z množico s 86 elementi niso operirali. Podobne rezultate je pokazala raziskava avtorjev Gilmor, McCarthy in Spelke (2007), v kateri so 5- do 6-letni otroci pokazali razumevanje simbolnega računanja, čeprav se s formalnim učenjem simbolne aritmetike še niso srečali. V eksperimentu so se otroci iz različnih socialno-kulturnih okolij odločali, kdo ima več bombonov, Sarah ali John. Naloga je bila strukturirana tako: »Sarah je imela 21 bombonov, John pa 34. Sarah je dobila še 30 bombonov. Kdo jih ima več?« Podoben eksperiment so ponovili $\mathrm{z}$ odvzemanjem bombonov. $\mathrm{V}$ obeh primerih je bila razlika med pravilnimi in nepravilnimi odgovori statistično pomembna, večinoma (64\%) so otroci odgovarjali pravilno. Zanimiva pa je bila tudi ugotovitev, da je pravilnost odgovorov korelirala $\mathrm{s}$ preizkusi znanja, ki ga razvija šolski kurikulum. Zato so zaključili, da je sposobnost aproksimativne simbolne aritmetike otrokom dana in je neodvisna od socialnega statusa ter okolja, v katerem otrok odrašča, in ne temelji na znanju natančne aritmetike (Gilmor idr., 2007). Podobno so že Dehaene, Spelke, Pinel, Stanescu in Tsivkin (1999) ugotovili, da je natančna aritmetika povezana z govornimi sposobnostmi in aktivacijo besednih asociacij, medtem ko je aproksimacija številčnosti neodvisna od jezika in je povezana $\mathrm{z}$ vidno-prostorskim procesiranjem.

\section{Aritmetika}

Tako za otroke kot odrasle velja, da je čas seštevanja odvisen od velikosti manjšega člena. Poleg tega so raziskovalci (De Smedt, Holloway in Ansari, 2011; Dehaene, 1997) tudi ugotovili, da je čas za množenje dveh števk enak času seštevanja le-teh. Lahko bi rekli, da je tudi čas množenja odvisen od istega dejavnika, tj. od velikosti manjšega faktorja. Z vstopom otrok v izobraževalni sistem pa se učenje aritmetike spremeni v učenje algoritmov, katere otroci izvajajo po spominu in jih avtomatizirajo. Zato lahko rečemo, da imata za mladostnike delovni in dolgoročni spomin zelo pomembno vlogo pri mentalnem računanju. Aritmetično procesiranje zahteva kompleksno aktivacijo več možganskih predelov. Pri računanju se aktivirajo parietalna, prefrontalna in cingularna skorja (Chochon idr., 1999; Dehaene idr., 2004). Intraparietalni sulkus, še posebej njegov horizontalni del, je aktiven pri številskih nalogah in pri predstavitvah količine. Precentralni in inferiorni prefrontalni korteks pa sta aktivna pri mentalnem računanju (Dehaene idr., 2004). Parietalni korteks (PC) in prefrontalni korteks (PFC) sta funkcionalno povezana, saj se numerična informacija iz PC prenese v PFC, kjer se zadrži do primernega odgovora oz. vedenja. Ti področji sprejemata abstraktne informacije o količini in sta pomembni za izvršitvena dejanja, kamor sodijo kategorizacija, odločanje, pa tudi delovni spomin (Nieder in Dehaene, 2009). Računanje z večmestnimi števili je še nekoliko bolj kompleksen in dolgotrajen proces, pri katerem se še dodatno aktivira prefrontalni reženj. Področje PFC je pomembno za izvrševanje kontrole, za delovni spomin in za pripravo odgovora. Za strategije reševanja aritmetičnih problemov lahko rečemo, da $\mathrm{z}$ odraščanjem oziroma $\mathrm{z}$ vajo postanejo avtomatične ter odvisne od priklica aritmetičnih dejstev iz spomina. Vendar pa po nekaterih raziskavah načrtovanje reševanja problemov in uporaba delovnega spomina v odrasli dobi s staranjem upada (Rivera, Reiss, Eckert in Menon, 2005).

Glavna prednost računanja po spominu je hitrejši čas izračuna, poveča pa se delež napačnih odgovorov. Ko otroci preidejo na spominsko računanje, se njihova intuicija za števila začne zmanjševati. Praktično sočasno se jim matematika začne dozdevati težka. Človeški spomin deluje namreč asociativno, dogodek v spominu se poveže z ostalimi podatki, dogodki in občutji. Zato je memoriziranje tabel (npr. za množenje) težko, v aritmetiki pa se $\mathrm{z}$ uporabo spomina porodi tudi veliko neverjetnih napak, npr. $3+4=12 ; 0,2+3=0,5 ; 1 / 5+2 / 5=3 / 10$ ipd. Učenje matematičnih tabel naj bi bilo povezano $\mathrm{z}$ verbalnim spominom, in šele ko spomin odpove, si pomagamo $\mathrm{z}$ alternativnimi strategijami (Dehaene, 1997).

Na sliki 1 smo po navedenih raziskavah povzeli okvirne faze razvoja aritmetičnih sposobnosti pri dojenčkih in otrocih. Faze razvoja smo umestili časovno tako, kot so bile opisane $\mathrm{v}$ raziskavah, pri čemer smo za pričetek razvojne faze izbrali najnižjo starost, pri kateri je bila sposobnost že opisana.

Da usvojimo matematično znanje, se mora $\mathrm{v}$ možganih fleksibilno povezati več predelov, števila je potrebno povezati z besedami in s količinsko predstavo, izbrati je potrebno najbolj ustrezno metodo za reševanje določenega problema. Pri tem ima šolanje ključno vlogo, saj je potrebno algoritmom dati pomen in razumevanje. Predšolski otroci imajo dobro razvito matematično intuicijo, znajo oceniti številčnost skupine, preštevajo, seštevajo in odštevajo, vendar na svoj intuitiven način. Čeprav je osnovno razumevanje številčnosti vrojeno, pa se večino aritmetike naučimo v šoli. Ker gre za neke vrste miselni preskok, žal prav z učenjem aritmetike, predvsem $\mathrm{z}$ učenjem algoritmov, pri otrocih intuicijo zameglimo. To pa povzroči, da postane matematika težka in nepriljubljena. Vendar je potrebno poudariti, da ima intuitivno določanje števila elementov oz. količine s pomočjo mentalne številske osi ključni pomen za razumevanje matematike (Dehaene, 1997; Gilmore, 


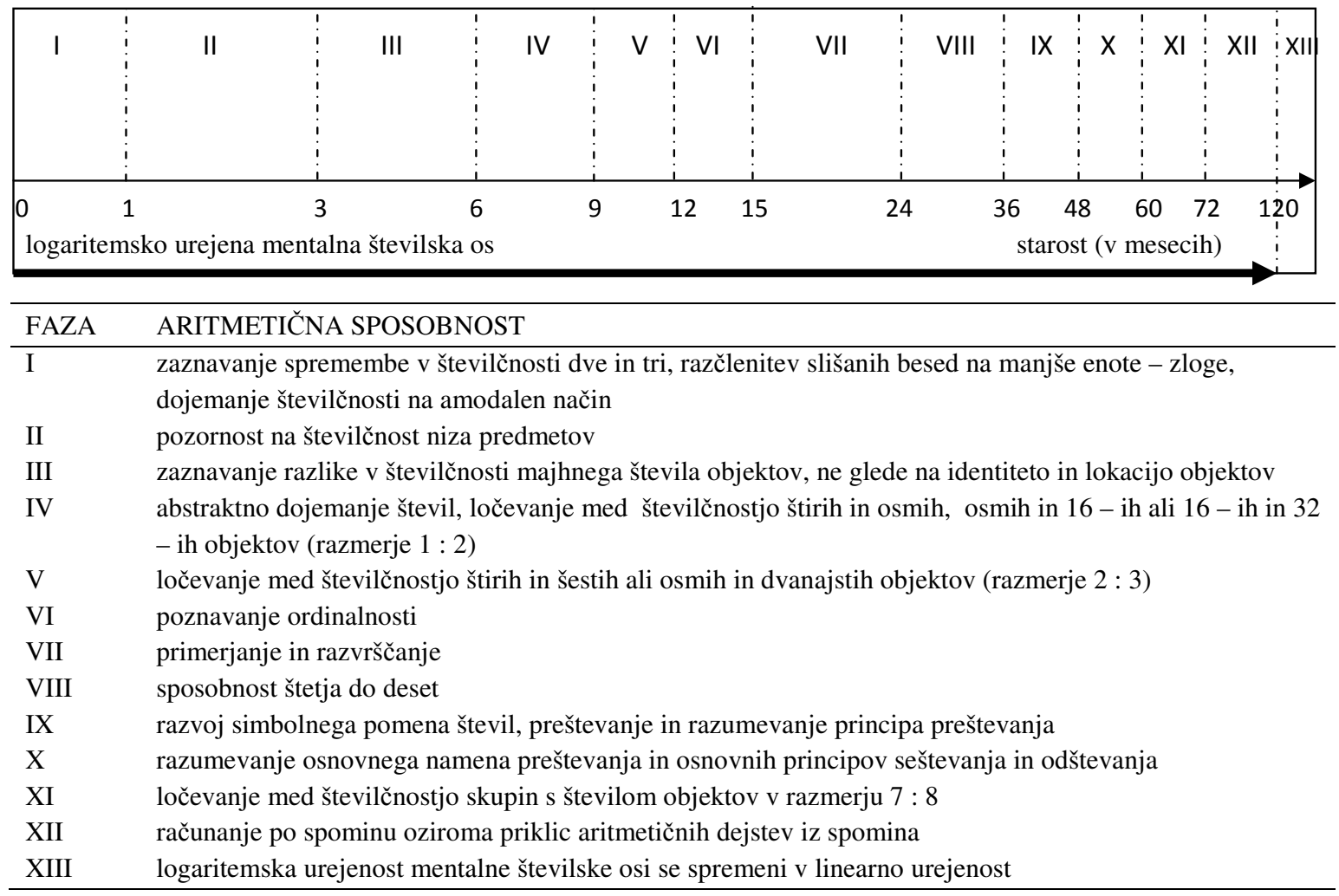

Slika 1. Okvirne faze razvoja aritmetičnih sposobnostih pri dojenčkih in otrocih, pri čemer je označena najzgodnejša starost, ko je aritmetična sposobnost že opisana v študijah. Tabela je povzeta po raziskavah Gelman in Gallistel, 1978; Antell in Keating, 1983; Starkey idr., 1990; Van Loosbroek in Smitsman, 1990; Bijeljac-Babič idr., 1993; Dehaene idr., 2004; Lipton in Spelke 2003, 2004, 2006; Feigenson idr., 2004; Xu idr., 2005; Dehaene, 1997, 2009; Hyde, 2011; De Smedt idr., 2011.

McCarthy in Spelke, 2010). Halloway in Ansari (2008, v Dehaene, 2009) sta proučevala 6- do 8-letne otroke in ugotovila, da je sposobnost primerjanja dveh števil napovednik matematične uspešnosti in da uspešnost nesimbolnega primerjanja števil napove matematične dosežke preko celotnega šolanja (Halberda idr., 2008; v Dehaene, 2009). Zadnje raziskave nakazujejo tudi, da je avtomatična kvantifikacija simbolnih števil ključna sposobnost za razvoj matematičnih kompetenc (De Smedt in Gilmore, 2011, v Grabner, Reishofer, Koschutnig in Ebner, 2011). Zato lahko sklepamo, da matematična intuicija predstavlja osnovo matematičnih sposobnosti, ki jo lahko, ali celo moramo, nadgraditi z učenjem aritmetike, vendar pa je ob tem ne smemo zanemariti.

\section{Zaključek}

Raziskave o razvoju aritmetičnih sposobnosti segajo že v sredino prejšnjega stoletja (npr. teorija J. Piageta), kljub novejšim raziskavam o razvoju aritmetičnih sposobnosti v predšolskem obdobju in pomembnosti le-tega pa se še vedno premalo zavedamo pomena učenja aritmetike $\mathrm{v}$ otroštvu. Novejše raziskave so namreč pokazale, da je bilo staro prepričanje, da otroci $\mathrm{v}$ predšolskem obdobju niso dovzetni za aritmetiko, zmotno. Občutek za količino in števila nam je vrojen, učenje aritmetike $\mathrm{z}$ začetkom že v predšolskem obdobju pa ima velik vpliv na razvoj matematičnih sposobnosti v kasnejšem šolanju (Maryam, Mahnaz in Hasan, 2011). Dobro poznavanje števil je namreč predpogoj za uspešno razumevanje matematike. Zato se moramo zavedati velikega pomena učenja števil in aritmetike še pred začetkom formalnega izobraževanja, vendar pa moramo otrokom tako v predšolskem obdobju kot v času šolanja pomagati in omogočiti, da uporabljajo matematično intuicijo pri izgradnji miselnih modelov aritmetičnih algoritmov. Algoritmom je zato potrebno dati pomen, razumevanje, tako da jih ponazorimo plastično in $\mathrm{z}$ asociacijami iz vsakdanjega življenja. Števila je potrebno povezati z besedami in s količinsko predstavo. Matematično intuicijo moramo negovati in razvijati, kljub temu pa ne smemo zanemariti vloge spomina pri učenju aritmetike. Zato je pomembno, da spomin urimo (spominske igre, treningi spomina, recitiranje pesmi ...), učno snov pa ponavljamo, saj le to zagotavlja kontinuiteto znanja. Tega bi se morali zavedati starši, vzgojitelji in učitelji ter bi v delo $\mathrm{z}$ otroki tudi v predšolskem obdobju morali vključiti čim več matematičnih vsebin (npr. izštevanke, igranje s števili, razvrščanje, primerjanje...). Splošno prepričanje, da so te vsebine težke, je napačno. Otroci so zmožni učenja raznovrstnih vsebin, so izjemni v svoji domišljiji in intuiciji, odrasli pa žal velikokrat podcenjujemo njihove sposobnosti. Z zaupanjem v njihove 
zmožnosti jim lahko približamo matematične vsebine in jih učimo aritmetiko na sproščen, intuitiven način. Le tako lahko pričakujemo, da bo razumevanje matematike boljše, razvoj matematičnih sposobnosti pa hitrejši in uspešnejši.

\section{Literatura}

Antell, S. E. in Keating, D. P. (1983). Perception of numerical invariance in neonates. Child Development, 54, 695-701.

Batistič Zorec, M. (2006). Teorije v razvojni psihologiji. Ljubljana: Pedagoška fakulteta Univerze v Ljubljani.

Bijeljac-Babič, R., Bertoncini, J. in Mehler, J. (1993). How do 4-day-old infants categorize multisyllabic utterances? Developmental Psychology, 29(4), 711-721.

Brannon, E. M. (2002). The development of ordinal numerical knowledge in infancy. Cognition, 83(3), 223-240.

Bregant, T. (2012). Razvoj, rast in zorenje možganov [Brain development, growth, and maturation]. Psihološka obzorja, 21(2), 51-60.

Chochon, F., Cohen, L., Moortele, P. F. in Dehaene, S. (1999). Differential contributions of the left and right inferior parietal lobules to number processing. Journal of Cognitive Neuroscience, 11, 617-630.

De Smedt, B., Holloway, I. D. in Ansari, D. (2011). Effects of problem size and arithmetic operation on brain activation during calculation in children with varying levels of arithmetical fluency. NeuroImage, 57, 771-781.

Dehaene, S. (1997). The number sense: How the mind creates mathematic. Oxford: Oxford University Press.

Dehaene, S. (2009). Origins of mathematical intuitions: The case of arithmetic. Annals of the New York Academy of Sciences, 1156, 232-259.

Dehaene, S., Molko, N., Cohen, L. in Wilson, A. J. (2004). Arithmetic and the brain. Current Opinion in Neurobiology, 14, 218-224.

Dehaene, S., Spelke, E. S., Pinel, P., Stanescu, R. in Tsivkin, S. (1999). Sources of mathematical thinking: Behavioral and brain-imaging evidence. Science, 284, 970-974.

Feigenson, L., Dehaene, S. in Spelke, E. (2004). Core systems of number. Trends of Cognitive Science, 8(7), 307-314.

Gelman, R. in Gallistel, C. R. (1978). The child's understanding of number. Cambridge: Harvard University Press.

Gilmore, C. K., McCarthy, S. E. in Spelke, E. S. (2007). Symbolic arithmetic knowledge without instruction. Nature, 447, 589-591.

Gilmore, C. K., McCarthy, S. E. in Spelke, E. S. (2010). Non-symbolic arithmetic abilities and mathematics achievement in the first year of formal schooling. Cognition, 115(3), 394-406.
Grabner, R. H., Reishofer, G., Koschutnig, K. in Ebner, F. (2011). Brain correlates of mathematical competence in processing mathematical representations. Frontiers in Human Neuroscience, 5, 130.

Hyde, D. (2011). Two systems of non-symbolic numerical cognition. Frontiers in Human Neuroscience, 5, 150.

Lipton, J. S. in Spelke, E. S. (2003). Origins of number sense: Large number discrimination in human infants. Psychological Science, 14(5), 396-401.

Lipton, J. S. in Spelke, E. S. (2004). Discrimination of large and small numerosities by human infants. Infancy, 5(3), 271-290.

Lipton, J. S. in Spelke, E. S. (2006). Preschool children master the logic of number word meanings. Cognition, 98(3), B57-B66.

Marjanovič Umek, L., Kroflič, R., Videmšek, M., Kovač, M., Kranjc, S., Saksida, I., ... Japelj Pavešič, B. (2001). Otrok v vrtcu: Priročnik h kurikulu za vrtce. Maribor: Založba Obzorja.

Maryam, A., Mahnaz, E. in Hasan, A. (2011). Comparing the impact of number sense on mathematics achievement in both dyscalculia and normal students. Procedia - Social and Behavioral Sciences, 28, 5-9.

Michel, G. F. in Tyler, A. N. (2005). Critical period: A history from transitions of questions from when, to what, to how. Developmental psychobiology, 46(39), 156-162.

Nieder, A. in Dehaene, S. (2009). Representation of number in the brain. Annual Review of Neuroscience, 32, 185-208.

Rivera, S. M., Reiss, A. L., Eckert, M. A. in Menon, V. (2005). Developmental changes in mental arithmetic: Evidence for increased functional specialization in the left inferior parietal cortex. Cerebral Cortex, 15, 1779-1790.

Starkey, P., Spelke, E. S. in Gelman, R. (1990). Numerical abstraction by human. Cognition, 36, 97-128.

Van Loosbroek, E. in Smitsman, A. W. (1990). Visual perception of numerosity in infancy. Developmental Psychology, 26(6), 916-922.

$\mathrm{Xu}$, F., Spelke, E. S. in Goddard, S. (2005). Number sense in human infants. Developmental Science, $8(1)$, 88-101. 